\title{
STRATEGI PENGEMBANGAN BAWANG MERAH DI KABUPATEN BIMA, NUSA TENGGARA BARAT
}

\author{
THE STRATEGY OF SHALLOT DEVELOPMENT IN BIMA DISTRICT, NUSA \\ TENGGARA BARAT
}

\author{
Rima Setiani ${ }^{1)}$, Djoko Mulyono ${ }^{1)}$ dan Nurmalinda ${ }^{2)}$ \\ Pusat Penelitian dan Pengembangan Hortikultura ${ }^{1}$ \\ Balai Pengkajian Teknologi Pertanian DKI Jakarta ${ }^{2}$, \\ rimasetiani@yahoo.com
}

\begin{abstract}
Abstrak
Nusa Tenggara Barat (NTB) merupakan penghasil bawang merah terbesar nomor empat di Indonesia, setelah Jawa Tengah, Jawa Timur dan Jawa Barat dengan produksi rata-rata bawang merah adalah 10.22 ton/ha. Salah satu daerah potensial penghasil bawang merah di NTB adalah Kabupaten Bima yang ditetapkan pemerintah sebagai kawasan pengembangan bawang merah. Tujuan penelitian ialah untuk mengetahui faktor-faktor yang mempengaruhi pengembangan bawang merah dan menentukan strategi pengembangan bawang merah yang tepat untuk dilaksanakan di Kabupaten Bima. Penelitian dilakukan pada bulan Januari-Desember 2016. Metode analisis dilakukan secara deskriptif dan menggunakan SWOT. Pengembangan bawang merah di Kabupaten Bima mempunyai kekuatan yang lebih besar dari kelemahan, namun terdapat ancaman yang besar pula dibandingkan dengan peluang yang ada. Untuk itu strategi yang terbaik berada pada kuadran II yaitu strategi Strength-Threat (ST). Strategi yang disarankan adalah penerapan teknologi budidaya dan pengaturan pola tanam dengan memanfaatkan varietas lokal Keta Monca dan Super Philips. Selain itu, peningkatan peran Bulog dan penambahan fasilitas gudang untuk menyimpan bawang merah saat panen raya.
\end{abstract}

Kata Kunci: Bawang Merah, Strategi, SWOT

Klasifikasi JEL : O13, O21

\begin{abstract}
Nusa Tenggara Barat is the fourth largest of shallot producer in Indonesia, after Central Java, East Java and West Java. The average of yield is 10.22 tons / ha. Bima district has been selected by Government to be a shallot development cluster. The purpose of this study were to determine factors which affect shallot development and to formulate strategy should be implemented in Bima district. The study was conducted from January to December 2016. The shallot development in Bima district has greater strengths than weaknesses, however there were potential threats compared to existing opportunities. The best strategy was Strength-Threat strategy (ST). The suggested strategy is the cultivation technology application and management of cropping pattern by utilizing local varieties Keta Monca and Super Philips. In addition, Bulog optimized its function and added warehouse facilities to store shallot during the harvest period.
\end{abstract} Key words: Development, Shallot, Strategy, SWOT

JEL Clasification : O13, O21 


\section{PENDAHULUAN}

Sentra produksi bawang merah di Indonesia adalah Pulau Jawa dengan total produksi sebesar 956.652 ton atau sekitar 77,53\% dari total produksi bawang merah nasional. Provinsi Jawa Tengah merupakan penghasil bawang merah terbesar, dengan produksi sebesar 519.356 ton atau sebesar $42,09 \%$ dari total produksi bawang merah nasional, diikuti Jawa Timur dan Jawa Barat. Untuk luar Jawa, provinsi penghasil bawang merah terbesar ialah Nusa Tenggara Barat, dengan produksi sebesar 117.513 ton atau sekitar 9,52\% dari total produksi bawang merah nasional, diikuti oleh Sumatera Barat (Sekretaris Direktorat Jenderal Hortikultura, 2015).

Kabupaten Bima merupakan salah satu sentra produksi di NTB yang ditetapkan pemerintah menjadi kawasan pengembangan bawang merah. Luas areal penanaman dari tahun 2014 semakin berkembang. Secara berturut-turut dari tahun 2014 ke 2016 adalah 8.207 Ha, 10.491 Ha, dan 13.674 Ha, dan produksinya adalah 91.709 ton, 125.057 ton dan 153.297 ton (Diperta Kab. Bima, 2015). Berkembangnya luas areal penanaman tersebut dipengaruhi oleh meningkatnya permintaan baik lokal maupun nasional. Dari tahun 2014-2016, tingkat konsumsi bawang merah per kapita masyarakat Indonesia, berturut-turut adalah 0,396 ons/minggu, 0,477 ons/ minggu, 0,520 ons/ minggu dan 0,542 ons/ha (BPS).

Sebagai salah satu sentra produksi bawang merah nasional, pengembangan bawang merah di Kabupaten Bima sangat penting dilakukan, guna memenuhi kebutuhan bawang merah yang terus meningkat secara nasional. Untuk itu diperlukan strategi dalam pengembangannya. Terkait dengan hal tersebut, tujuan penelitian ini adalah untuk mengetahui faktor-faktor yang mempengaruhi pengembangan bawang merah di Kabupaten Bima dan strategi pengembangannya.

\section{TINJAUAN PUSTAKA}

Bawang merah merupakan salah satu komoditas hortikultura bernilai tinggi (high value comodity) sehingga banyak petani yang mengusahakannya. Rata-rata produktivitas bawang merah di Indonesia pada tahun 2014 hanya mencapai 10,23 ton/ha, sedangkan potensial produktivitas bisa mencapai 20 ton/ ha. Pasokan bawang merah juga tidak tersedia sepanjang waktu karena budidaya bawang merah dilakukan secara musiman, yaitu pada musim kemarau antara bulan April-September (on season) (Aldila, Fariyanti, \& Tinaprilla, 2017).

Konsumsi bawang merah penduduk Indonesia sejak tahun 1993-2012 menunjukkan perkembangan yang fluktuatif namun relatif meningkat. Konsumsi rata-rata bawang merah untuk tahun 1993 adalah $1,33 \mathrm{~kg} / \mathrm{kapita} /$ tahun dan pada tahun 2012 konsumsi bawang merah telah mencapai $2,764 \mathrm{~kg} / \mathrm{kapita} / \mathrm{tahun}$. Peningkatan permintaan bawang merah tersebut tidak diikuti dengan peningkatan produksi bawang merah nasional (Mehran, Kesumawati, \& Sufardi, 2013).

Pemerintah mencanangkan program untuk meningkatkan produktivitas, antara lain melalui kegiatan Upaya Khusus (UPSUS) untuk komoditas bawang merah dan cabai merah berdasarkan Kepmentan Nomor 377/Kpts/RC.210/6/2015 tentang Pokja Upsus Gerakan Peningkatan Produksi Cabai dan Bawang Merah melalui APBNP TA 2015. Selain itu Pemerintah menetapkan kawasan pengembangan bawang merah berdasarkan Keputusan Menteri Nomor 45/ $\mathrm{Kpts} / \mathrm{PD} / \mathrm{I} / 2015$ dimana Kabupaten Bima menjadi salah satu wilayah pengembangan bawang merah.

Dengan ditetapkannya kabupaten Bima sebagai wilayah pengembangan kawasan bawang merah oleh pemerintah, maka diperlukan strategi dari hulu ke hilir. Keberhasilan pengembangan bawang merah dipengaruhi dengan penerapan teknologi budidaya yaitu penggunaan varietas unggul yang sesuai, benih bermutu, pemupukan, pengendalian hama dan penyakit dan gulma, serta perbaikan teknologi pasca panen (Simatupang, 2017). Hal ini diperkuat oleh (Mayrowani \& Darwis, 2007) bahwa keberhasilan budidaya tanaman bawang merah sangat ditentukan oleh intensitas pemeliharaan tanaman yang dilakukan petani. Selain itu juga dipengaruhi faktor pemasaran dan perdagangan yang meliputi pengembangan unit usaha bersama (koperasi atau usaha berbadan hukum lainnya) serta 
pengembangan sistem informasi (harga penawaran dan permintaan produk) untuk mendukung upaya menangkap peluang pasar (Santoso, 2013).

Analisis SWOT merupakan analisis kondisi internal maupun eksternal yang selanjutnya digunakan sebagai dasar merancang strategi. Faktor internal meliputi penilaian terhadap faktor kekuatan (Strength) dan kelemahan (Weakness), sedangkan faktor eksternal mencakup faktor peluang (Opportunity) dan tantangan (Threath). Analisis SWOT banyak digunakan dalam menganalisis strategi pengembangan suatu komoditas (Aji, Satria, \& Hariono, 2014; Enteding, Handayani, \& Adam, 2016; Putra \& Djalante, 2016; Rauf, Darman, \& Andriana, 2015; Santoso, 2013; Waridjo \& Fallo, 2016).

\section{METODE PENELITIAN}

Penelitian dilakukan di desa Soki dan Renda, Kecamatan Belo, serta desa Risa, Kecamatan Woha Kabupaten Bima, Nusa Tenggara Barat pada bulan Januari sampai Desember 2016. Pemilihan lokasi penelitian dilakukan secara sengaja dengan pertimbangan lokasi tersebut merupakan sentra produksi bawang merah di Kab. Bima.

Data primer diperoleh melalui focus group discussion (FGD), wawancara dan penyebaran kuesioner. Responden penelitian berjumlah 34 orang yang dipilih secara sengaja mewakili key actors dalam pengembangan bawang merah, yang terdiri dari petani, ketua kelompok tani, penyuluh, perwakilan dari Pemerintah Daerah Kabupaten Bima, dan perwakilan Balai Pengkajian Teknologi Pertanian NTT. Wawancara dilakukan dengan Kepala Dinas Pertanian Kabupaten Bima, Wakil dari Bappeda Kabupaten Bima, Kepala Bidang Hortikultura provinsi NTB, Dinas Perdagangan dan Industri, serta Dinas Pekerjaan Umum Kabupaten Bima. Responden menjawab kuesioner dengan 5 pilihan, yaitu sangat setuju, setuju, tidak memutuskan, tidak setuju dan sangat tidak setuju (Likert 1932 dalam Budiaji, 2013). Data primer dianalisis dengan menggunakan Strengths, Weakness, Opportunities, Threats (SWOT).
Pendekatan SWOT secara kuantitatif digunakan untuk mengetahui secara pasti posisi Kabupaten Bima dalam pengembangan Bawang Merah, yaitu dengan melakukan perhitungan skor dan bobot, dan jumlah perkalian antara skor dan bobot pada setiap faktor S-W-O-T. Setelah itu dilakukan pengurangan antara $\mathrm{S}$ dan $\mathrm{W}$ untuk menentukan sumbu $\mathrm{x}$, dan pengurangan $\mathrm{O}$ dan T untuk menentukan sumbu y.

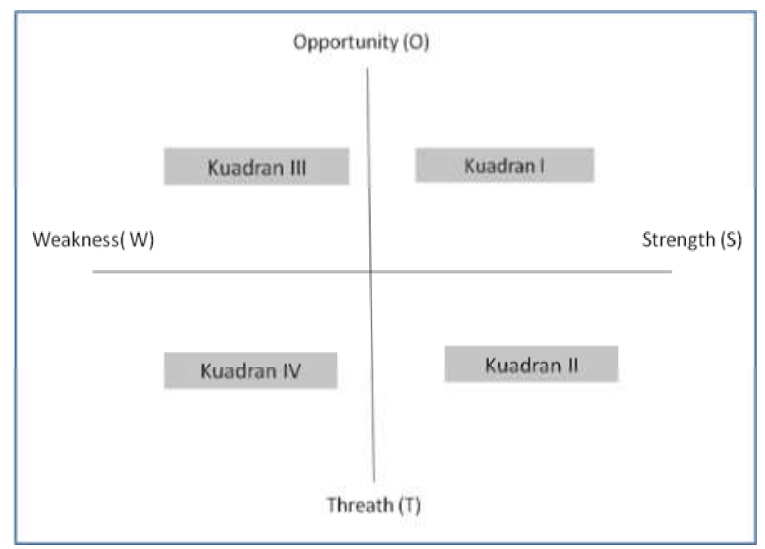

Gambar 1. Kuadran SWOT

Data sekunder yang dikumpulkan meliputi karakteristik wilayah, luas areal penanaman, luas areal panen, produksi dan produktivitas bawang merah dan data-data lain yang terkait dengan tujuan penelitian. Data sekunder diperoleh dari Dinas Pertanian Kabupaten Bima, Bappeda Kabupaten Bima dan Dinas Pertanian Provinsi NTB. Data sekunder dianalisis secara deskriptif sebagai data pendukung dalam penelitian.

\section{HASIL DAN PEMBAHASAN}

Kabupaten Bima merupakan salah satu kabupaten yang berada di ujung timur provinsi Nusa Tenggara Barat, dengan ibukotanya Woha. Luas lahan sawah pertanian adalah $34.874 \mathrm{Ha}$ dan 367.016 Ha lahan pertanian bukan sawah. Produktivitas bawang merah ditampilkan pada tabel berikut

Kondisi lahan sawah datar yang subur, kelembaban udara relatif rendah $(\mathrm{RH}= \pm 60$ $\%$ ), tingkat ketersediaan pengairan dengan sumur-sumur pantek yang cukup memadai (walaupun kondisi iklim relatif kering), sangat mendukung Kabupaten Bima sebagai sentra produksi bawang merah. Tanaman bawang merah tumbuh di daerah beriklim kering, 
Tabel 1. Produksi dan Produktivitas Bawang Merah Berdasarkan Kecamatan (Shallot Production on Sub District in Bima)

\begin{tabular}{|c|c|c|c|c|c|c|c|}
\hline No & Kecamatan & $\begin{array}{l}\text { Produktivitas } \\
(\mathrm{Ku} / \mathrm{Ha}) 2014\end{array}$ & $\begin{array}{c}\text { Produksi } \\
\text { (Ton) 2014 }\end{array}$ & $\begin{array}{l}\text { Produktivitas } \\
(\mathrm{Ku} / \mathrm{Ha}) 2015\end{array}$ & $\begin{array}{c}\text { Produksi } \\
\text { (Ton) 2015 }\end{array}$ & $\begin{array}{l}\text { Produktivitas } \\
(\mathrm{Ku} / \mathrm{Ha}) 2016\end{array}$ & $\begin{array}{c}\text { Produksi } \\
\text { (Ton) } 2016 \\
\end{array}$ \\
\hline$T$ & Sape & 114,73 & 16.969 & 125.59 & 17.872 & 120,26 & 27.202 \\
\hline 2 & Lambu & 116,49 & 25.792 & 122,63 & 26.414 & 116,20 & 23.333 \\
\hline 3 & Wawo & - & - & - & - & 115,00 & 69 \\
\hline 4 & Lambitu & 116 & - & 100.00 & 30 & 115,00 & 23 \\
\hline 5 & Longgudu & 105,56 & 58 & - & - & 0,00 & 0 \\
\hline 6 & Belo & 110,67 & 1.137 & 121.88 & 16.454 & 120,09 & 31.452 \\
\hline 7 & Palibelo & 116,82 & 166 & 11077 & 144 & 0,00 & 0 \\
\hline 8 & Woha & 118,89 & 4.556 & 120.69 & 22.267 & 118,13 & 18.475 \\
\hline 9 & Monta & - & 6.563 & 121.84 & 11.441 & 118,88 & 22.314 \\
\hline 10 & Parado & & - & - & - & 110,00 & 286 \\
\hline 11 & Bolo & 123,38 & 2.517 & 118.50 & 2.773 & 115,96 & 2.586 \\
\hline 12 & Madapangga & - & - & - & - & 0,00 & 0 \\
\hline 13 & Wera & 100,17 & 10.378 & 118.25 & 10.820 & 117,19 & 9.668 \\
\hline 14 & Ambalawi & 109,17 & 1.310 & 109.77 & 3.293 & 107,97 & 2.494 \\
\hline 15 & Donggo & - & - & - & - & 0,00 & 0 \\
\hline 16 & Soromandi & 128,79 & 11.913 & 127.73 & 13.067 & 123,89 & 14.755 \\
\hline 17 & Sanggar & 92,50 & 148 & 123.91 & 285 & 117,71 & 412 \\
\hline \multirow[t]{2}{*}{18} & Tambora & - & - & 115.88 & 197 & 114,00 & 228 \\
\hline & Jumlah & 114.25 & 91.709 & 122.14 & 125.057 & 118,94 & 153.297 \\
\hline
\end{tabular}

Sumber: Dinas Pertanian Tanaman Pangan dan Hortikultura, 2016

Tabel 2. Faktor-faktor Yang Mempengaruhi Pengembangan Bawang Merah di kabupaten Bima (Factors which affect on Shallot Development in Bima District)

\begin{tabular}{|c|c|}
\hline No. & FAKTOR INTERNAL \\
\hline & KEKUATAN \\
\hline$\frac{1}{2}$ & $\begin{array}{l}\text { Ketersediaan lahan } \\
\text { Jklim vano mendukung }\end{array}$ \\
\hline 3 & Ketersediaan air \\
\hline & Petani sudah berpengalaman \\
\hline 5 & Petani sudah menghasilkan benih sendiri \\
\hline & Kelembagaan pemasaran cukup kuat (tengkulak, pedagang pengumpul desa, pedagang besar) \\
\hline 7 & Memiliki varietas lokal yang sesuai untuk musim hujan dan kemarau. \\
\hline 8 & $\begin{array}{l}\text { Potensi produksi bawang merah di Bima lebih tinggi daripada potensi produksi bawang merah } \\
\text { nasional }(\geq 10,22 \mathrm{~kg} / \mathrm{ha})\end{array}$ \\
\hline \multirow{10}{*}{$\begin{array}{l}1 \\
2 \\
3 \\
4 \\
5 \\
6 \\
7\end{array}$} & KELEMAHAN \\
\hline & Petani kurang modal \\
\hline & Belum ada penerapan paket teknologi \\
\hline & Organisasi penangkar benih belum ada \\
\hline & Organisasi petani tidak efektif \\
\hline & Tingkat pendidikan petani rendah \\
\hline & Penggunaan sarana produksi anorganik (pupuk/ obat-obatan) tinggi \\
\hline & $\begin{array}{l}\text { Sarana dan prasarana (irigasi, mesin pompa air, hand tractor, kapal cepat pengangkut bawa- } \\
\text { ng merah antar pulau) belum memadai }\end{array}$ \\
\hline & \multirow{2}{*}{$\begin{array}{l}\text { FAKTOR EKSTERNAL } \\
\text { PELUANG }\end{array}$} \\
\hline & \\
\hline 1 & Permintaan pasar terhadap bawang merah tinggi \\
\hline 2 & Adanya dukungan pemerintah daerah dan pusat \\
\hline & Adanya pelabuhan di Bima \\
\hline & Adanya lembaga keuangan/Perbankan \\
\hline 5 & Meningkatnya aksesibilitas terhadap sumber pembiayaan \\
\hline & ANCAMAN \\
\hline 1 & Peralihan penggunaan lahan dari pertanian ke non pertanian (pemukiman) \\
\hline 2 & Melimpahnya bawang merah pada saat panen \\
\hline 3 & Masuknya bawang merah dari luar kabupaten Bima \\
\hline & Kurangnya tenaga kerja dalam usahatani bawang merah \\
\hline 5 & Tidak ada pola tanam \\
\hline 6 & Tingginya harga pupuk dan pestisida \\
\hline
\end{tabular}


Tabel 3. Hasil Analisis Faktor Internal (Internal Factor Analysis Summary, IFAS)

\begin{tabular}{|c|c|c|c|c|}
\hline No. & IFAS & Rating & Bobot & Skor \\
\hline A. & KEKUATAN & & & \\
\hline 1 & Ketersediaan lahan & 3,68 & 0,11 & 0,40 \\
\hline 2 & Iklim yang mendukung & 3,59 & 0,10 & 0,36 \\
\hline 3 & Ketersediaan air & 3,56 & 0,10 & 0,36 \\
\hline 4 & Petani sudah berpengalaman & 3,47 & 0,09 & 0,31 \\
\hline 5 & Petani sudah menghasilkan benih sendiri & 3,47 & 0,05 & 0,17 \\
\hline 6 & Kelembagaan pemasaran cukup kuat (tengkulak, pedagang & 3,50 & 0,07 & 0,25 \\
\hline 7 & $\begin{array}{l}\text { pengumpul desa, pedagang besar) } \\
\text { Memiliki varietas lokal yang sesuai untuk musim hujan dan }\end{array}$ & 3,29 & 0,03 & 0,10 \\
\hline \multirow[t]{2}{*}{8} & $\begin{array}{l}\text { kemarau } \\
\text { Potensi produksi bawang merah di Bima lebih tinggi dari- } \\
\text { pada potensi produksi bawang merah nasional }(\geq 10,22 \mathrm{Kg} /\end{array}$ & 3,53 & 0,06 & 0,21 \\
\hline & Sub total & 28,09 & & 2,16 \\
\hline B. & KELEMAHAN & & & \\
\hline 1 & Petani kurang modal & 3,26 & 0,08 & 0,26 \\
\hline 2 & Belum ada penerapan paket teknologi & 3,26 & 0,07 & 0,23 \\
\hline 3 & Organisasi penangkar benih belum ada & 3,41 & 0,02 & 0,07 \\
\hline 4 & Organisasi petani tidak efektif & 3,32 & 0,07 & 0,23 \\
\hline 5 & Tingkat pendidikan petani rendah & 3,35 & 0,07 & 0,23 \\
\hline 6 & Penggunaan sarana produksi anorganik (pupuk/ obat- & 3,24 & 0,02 & 0,06 \\
\hline 7 & $\begin{array}{l}\text { Satan) tinggi } \\
\text { torana kapal ceparana (irigasi, mesin pompa air, hand trac- } \\
\text { belum memadai }\end{array}$ & 3,15 & 0,04 & 0,13 \\
\hline
\end{tabular}

peka terhadap curah hujan dan intensitas hujan yang tinggi serta cuaca berkabut, membutuhkan sinar matahari minimal $70 \%$, suhu udara25-32 $\mathrm{C}$ dan kelembaban nisbi $50-70 \%$.

\section{Faktor-Faktor yang Mempengaruhi Pengembangan Bawang Merah}

Dari hasil penelitian teridentifikasi faktorfaktor dari dalam dan dari luar kabupaten Bima yang mempengaruhi pengembangan bawang merah yang meliputi kekuatan dan kelemahan, serta peluang dan ancaman (Tabel 2).

Dari hasil perhitungan matrik faktor internal, $\mathrm{m}$ aka diperoleh faktor-faktor kekuatan mempunyai nilai 2,16, lebih tinggi dari pada faktor-faktor kelemahan dengan nilai 1,22. Hal ini menunjukkan bahwa pengembangan bawang merah di Kabupaten Bima memiliki kekuatan yang lebih besar dibandingkan faktor kelemahannya. Kekuatan terbesar adalah tersedianya lahan pengembangan bawang merah yang subur, diikuti oleh iklim yang sesuai serta tersedianya air sepanjang tahun. Sedangkan kelemahan terbesar adalah kurangnya modal petani, belum adanya teknologi serta lemahnya kelembagaan petani dan penangkar, kelompok tani belum berfungsi optimal demikian pula penangkar benih.

Kekuatan yang lain adalah petani mempunyai pengalaman berbudidaya yang diperoleh dari kebiasaan turun temurun karena mereka percaya bahwa usahatani bawang merah meningkatkan pendapatan dan dapat menjadi penopang hidup keseharian, sehingga mereka tidak beralih untuk mengganti bawang merah dengan komoditas lain.

Dua varietas bawang merah yang sudah berkembang adalah varietas lokal Keta Monca yang ditanam pada musim hujan dan Super Philip yang ditanam pada musim kemarau. Sesuai dengan SK Menteri Pertanian Nomor 529/Kpts/PD.210/10/2013, dan varietas Super Philip, dilepas dengan SK Mentan No 66/Kpts/TP.240/2/2000 pada 25 Februari 2000. Kedua varietas tersebut disukai oleh petani dan konsumen bawang merah. Hal ini memberikan keuntungan bagi Kabupaten Bima, karena dapat menanam sepanjang tahun sehingga petani tidak bergantung pada bawang merah dari luar kabupaten Bima. Hal ini diperkuat oleh data dari (Kemendag, 2015), yang menyebutkan bawang merah Bima memiliki keunggulan yang tahan terhadap cuaca (panas ataupun hujan) sehingga dapat ditanam sepanjang tahun, serta mempunyai 
Tabel 4. Hasil Analisis Faktor Eksternal (External Faktor Analysis Summary, EFAS)

\begin{tabular}{clccc}
\hline $\begin{array}{c}\text { No. } \\
\text { C. }\end{array}$ & \multicolumn{1}{c}{$\begin{array}{c}\text { EFAS } \\
\text { PELUANG }\end{array}$} & Rating & Bobot & Skor \\
\hline 1 & Permintaan pasar terhadap bawang merah tinggi & 3,44 & 0,10 & 0,34 \\
2 & Adanya dukungan pemerintah daerah dan pusat & 3,24 & 0,09 & 0,29 \\
3 & Adanya pelabuhan di Bima & 3,53 & 0,09 & 0,32 \\
4 & Adanya lembaga keuangan/Perbankan & 2,79 & 0,07 & 0,20 \\
5 & Meningkatnya aksesibilitas terhadap sumber pembiay- & 2,47 & 0,07 & 0,17 \\
& aan & & \\
\hline & Sub total ANCAMAN & & 1,32 \\
\hline D. & Peralihan penggunaan lahan dari pertanian ke non per- & 2,56 & 0,10 & 0,26 \\
1 & tanian (pemukiman) & 3,29 & 0,13 & 0,43 \\
2 & Melimpannya bawang merah pada saat panen & 2,21 & 0,08 & 0,18 \\
3 & Masuknya bawang merah dari luar kabupaten Bima & 3,03 & 0,09 & 0,27 \\
4 & Kurangnya tenaga kerja dalam usahatani bawang & 2,85 & 0,09 & 0,26 \\
& merah & 3,62 & 0,09 & 0,33 \\
6 & Tidak ada pola tanam yang bagus & & & 1,72 \\
\hline
\end{tabular}

mutu yang baik serta tahan disimpan. Namun kelemahannya adalah benih yang digunakan belum berlabel dan belum ada pendampingan dari BPSB.

Pemasaran bawang merah dari Kabupaten Bima tidak ada kendala karena terdapat lima perusahaan yang merupakan pedagang besar yaitu UD Wajar, UD. Rade Bari, UD. Bintang Putra, UD Sinar Bumi dan UD. Muda Mandiri. Pedagang tersebut yang menghubungkan petani dengan konsumen kota. Mereka membeli bawang merah dari petani sekitar $10 \%$, dari pedagang pengumpul $50 \%$ dan pedagang lainnya $40 \%$. Dari pedagang besar, bawang merah dijual ke Jawa Tengah, Jawa Timur, Ujung Pandang, Kalimantan Utara dan Jakarta. Seperti yang diungkapkan oleh (Syahyuti, 1998), bahwa pedagang merupakan aktor dalam pemasaran sebagai motor penggerak dalam agribisnis

Kelemahan dalam pengembangan bawang merah adalah serangan hama dan penyakit. Hasil penelitian Wandschneider, 2012 di Kab. Bima, selain modal, keterbatasan lahan dan benih, kendala utama lain dalam penanaman bawang merah adalah hama dan penyakit tanaman. Menurut (Basuki, 2014) kendala penanaman bawang merah pada musim hujan antara lain: serangan penyakit, kabut, hama, dan hujan. Hal ini mendorong petani melakukan penyemprotan pestisida secara berlebih untuk mencegah serangan hama dan penyakit, akibatnya biaya untuk pestisida tinggi. Menurut R Andriyani, 2006, penggunaan pestisida berlebih, menyebabkan peningkatan biaya, pencemaran air dan tanah, merusak keseimbangan ekosistem bahkan dampak terhadap kesehatan.

Petani di lokasi penelitian belum sadar dampak penggunaan pestisida berlebih. Tujuan mereka adalah bagaimana mengendalikan hama dan penyakit untuk mendapatkan hasil tinggi. Padahal untuk meningkatkan produksi tidak hanya faktor pengendalian hama dan penyakit, namun perlunya input paket teknologi seperti pengolahan tanah, pengairan, serta ZPT dan pupuk berimbang (Irfan, 2013). Lebih lanjut Simatupang, 2017 menjelaskan dengan paket teknologi dapat meningkatkan pendapatan petani sebesar $629 \%$. Ketidaktahuan petani, dapat disebabkan kurangnya sumber informasi teknologi. Untuk itu peran penyuluh sangat penting sebagai mediator dari sumber teknologi kepada petani.

Selain itu, kelembagaan petani dan penangkar di lokasi penelitian belum kuat, pertemuan rutin untuk membicarakan masalah pertanian belum ada. Kelompok tani sudah terbentuk, namun belum berfungsi dengan baik. Hal ini juga menjadi penyebab lambatnya informasi teknologi yang diterima petani. Padahal menurut Anantanyu, 2011, adanya kelompok tani dapat mempercepat aksesibilitas permodalan, sarana dan prasarana serta mempermudah pemerintah dalam memfasilitasi bantuan ke petani. Pentingnya peran kelompok tani dapat mewujudkan pertanian yang terkonsolidasi sehingga dapat 
berproduksi secara optimal dan efisien Sadjad 2010 dalam Nuryanti \& K.S.Swastika, 2011.

Bila dilihat dari tabel 4 , terlihat bahwa faktor peluang mempunyai nilai 1,32 sedangkan faktor ancaman mempunyai nilai 1,72. Hal ini menunjukkan bahwa usaha pengembangan bawang merah di Kabupaten Bima terdapat banyak ancaman dari pada peluang pengembangannya. Ancaman terbesar adalah melimpahnya bawang merah pada saat panen raya sehingga harga turun serta tingginya harga pupuk dan pestisida. Peluang terbesar dalam pengembangan bawang merah di kabupaten Bima adalah permintaan pasar terhadap bawang merah tinggi dan sarana transportasi dari daerah produsen ke daerah konsumen cukup memadai.

Permintaan bawang merah dari luar kabupaten Bima tinggi. Hal ini ditunjukkan dengan pengiriman oleh pedagang besar ke Manado, Pontianak, Jawa Tengah, Jawa Timur, Kalimantan Timur, Kalimantan Selatan, dan Maluku. Jumlah pengiriman ke daerah tersebut rata-rata 4-5 truk per minggu, atau $32-40$ ton per minggu, bahkan pada saat panen raya dapat mencapai 3-4 truk per hari.

Keuntungan lain adalah adanya pelabuhan di kabupaten Bima yang merupakan peluang besar mendukung pemasaran bawang merah. Jarak antara pedagang besar bawang merah dengan pelabuhan hanya 7 km. Seperti dikatakan oleh Putra 2011, pelabuhan mempunyai peran penting dalam perdagangan dan memberikan kontribusi untuk perekonomian nasional, dengan adanya pelabuhan dapat mengurangi biaya produksi khususnya ongkos transportasi (Putra \& Djalante, 2016). Sarana transportasi yang digunakan para pedagang besar dalam mendistribusikan bawang merah adalah menggunakan truk yang sudah dimiliki oleh para pedagang besar, dan menggunakan kapal melalui pelabuhan Bima untuk distribusi ke luar pulau.

Peluang lainnya adalah pada tahun 2016 Kabupaten Bima mendapatkan dukungan dari pemerintah pusat melalui dana Direktorat Jenderal Hortikultura ke Provinsi NTB untuk pengembangan seluas $1300 \mathrm{Ha}$, meliputi 13 kecamatan sentra bawang merah di Kabupaten Bima. Bantuan tersebut dialokasikan untuk bibit, sarana produksi serta alsintan seperti pompa air, cultivator. Walaupun sebenarnya sarana prasarana tersebut masih sangat kurang untuk mendukung pengembangan bawang merah secara massal. Sedangkan untuk lembaga keuangan/perbankan di Kabupaten Bima sudah ada mulai dari lembaga perbankan sampai koperasi tetapi lembaga keuangan ini belum memberikan kesempatan kepada petani untuk memberikan pinjaman dalam usahataninya.

Ancaman yang perlu diantisipasi adalah anjloknya harga saat panen raya, ditambah lagi dengan masuknya bawang merah dari luar kabupaten Bima. Pada saat itu harga turun menjadi dibawah Rp 10.000,- pada bulan Juli - Oktober Harga suatu komoditas anjlok ketika panen raya adalah fenomena pasar yang sering dihadapi (Suryani, Erwidodo, \& Anugerah, 2014). Ancaman lain adalah bawang merah ditanam sepanjang tahun, hal ini mengakibatkan ledakan hama dan penyakit, padahal harga pestisida tinggi, sehingga meningkatkan biaya produksinya yang akhirnya menurunkan pendapatan petani.

\section{Strategi Pengembangan Bawang Merah di Kabupaten Bima}

Matrik SWOT menunjukkan beberapa alternatif strategi yaitu pada tabel 5 .

Pengembangan bawang merah di Kabupaten Bima berada pada kuadran II (positif, negatif) (Gambar 2). Ini menunjukkan bahwa sebenarnya terdapat kekuatan dalam mengembangkan bawang merah di Kabupaten Bima, namun ancaman yang dihadapi juga besar.

Rekomendasi strategi yang bisa diberikan ialah perlunya diversifikasi strategi untuk menjadikan ancaman sebagai kekuatan, seperti pada matriks IFAS dan EFAS (Tabel 6), strategi yang terbaik adalah strategi Strength-Threat (ST) dengan nilai terbesar $(3,88)$, yaitu dengan menggunakan kekuatan yang ada untuk mengatasi ancaman yang mungkin timbul. (Rahayu, 2011) 
Tabel 5. Matrik SWOT (SWOT Matrix)

\begin{tabular}{|c|c|c|}
\hline EFAS & $\begin{array}{l}\text { Strength (S) } \\
\text { 1. Ketersediaan lahan } \\
\text { 2. Iklim yang mendukung } \\
\text { 3. Ketersediaan air } \\
\text { 4. Petani memiliki pengalaman } \\
\text { 5. Kelembagaan pemasaran } \\
\text { cukup baik } \\
\text { 6. Petani sudah menghasilkan } \\
\text { benih sendiri } \\
\text { 7. Memiliki varietas lokal yang } \\
\text { sesuai untuk musim hujan } \\
\text { dan kemarau } \\
\text { 8. Potensi produksi bawang } \\
\text { merah di Bima lebih tinggi } \\
\text { dari produksi bawang merah } \\
\text { nasional (> 10,22 Kg/Ha) }\end{array}$ & $\begin{array}{l}\text { Weaknesses (W) } \\
\text { 1. Petani kurang modal } \\
\text { 2. Belum ada penerapan paket } \\
\text { teknologi } \\
\text { 3. Tingkat pendidikan petani masih } \\
\text { rendah } \\
\text { 4. Organisasi petani tidak efektif } \\
\text { 5. Sarana dan prasarana (irigasi, } \\
\text { mesin pompa air, hand tractor, } \\
\text { kapal cepat pengangkut bawang } \\
\text { merah antar pulau) belum memadai } \\
\text { 6. Organisasi penangkar benih belum } \\
\text { ada } \\
\text { Penggunaan sarana produksi } \\
\text { anorganik (pupuk/ obat-obatan) } \\
\text { tinggi . }\end{array}$ \\
\hline $\begin{array}{l}\text { Opportunities }(\mathrm{O}) \\
\text { 1. Permintaan pasar terhadap } \\
\text { bawang merah tinggi } \\
\text { 2. Adanya pelabuhan di Bima } \\
\text { 3. Adanya dukungan pemerintah } \\
\text { daerah dan pusat } \\
\text { 4. Adanya lembaga keuangan/ } \\
\text { Perbankan } \\
\text { 5. Meningkatnya aksesibilitas } \\
\text { terhadap sumber pembiavaan }\end{array}$ & $\begin{array}{l}\text { 1. Pengembangan luasan } \\
\text { produksi bawang merah } \\
\text { 2. Menghasilkan benih } \\
\text { bersertifikat }\end{array}$ & $\begin{array}{l}\text { 1. Peningkatan fungsi organisasi } \\
\text { petani dalam mengelola dan } \\
\text { memfasilitasi anggotanya untuk } \\
\text { mengakses modal dari lembaga } \\
\text { keuangan } \\
\text { 2. Meningkatkan kapasitas petani } \\
\text { melalui transfer teknologi }\end{array}$ \\
\hline $\begin{array}{l}\text { Threats (T) } \\
\text { pada saat panen } \\
\text { 2. Tingginya harga pupuk dan } \\
\text { pestisida } \\
\text { 3. Kurangnya tenaga kerja } \\
\text { dalam usahatani bawang } \\
\text { merah } \\
\text { 4. Peralihan penggunaan } \\
\text { lahan dari pertanian ke non } \\
\text { pertanian (pemukiman) } \\
\text { 5. Tidak ada pola tanam } \\
\text { 6. Masuknya bawang merah dari } \\
\text { luar kabupaten Bima }\end{array}$ & $\begin{array}{l}\text { Strategi ST } \\
\text { 1. Mengatur pola tanam dengan } \\
\text { memanfaatkan varietas lokal } \\
\text { 2. Pengenalan teknologi } \\
\text { budidaya bawang merah } \\
\text { sehingga dapat mengurangi } \\
\text { penggunaan pestisida } \\
\text { 3. Meningkatkan peran } \\
\text { kelembagaan pemasaran } \\
\text { 4. Keterlibatan pemerintah } \\
\text { dalam menyerap panen }\end{array}$ & $\begin{array}{l}\text { Strategi WT } \\
\text { 1. Mempertahankan } \\
\text { bawang merah }\end{array}$ \\
\hline
\end{tabular}

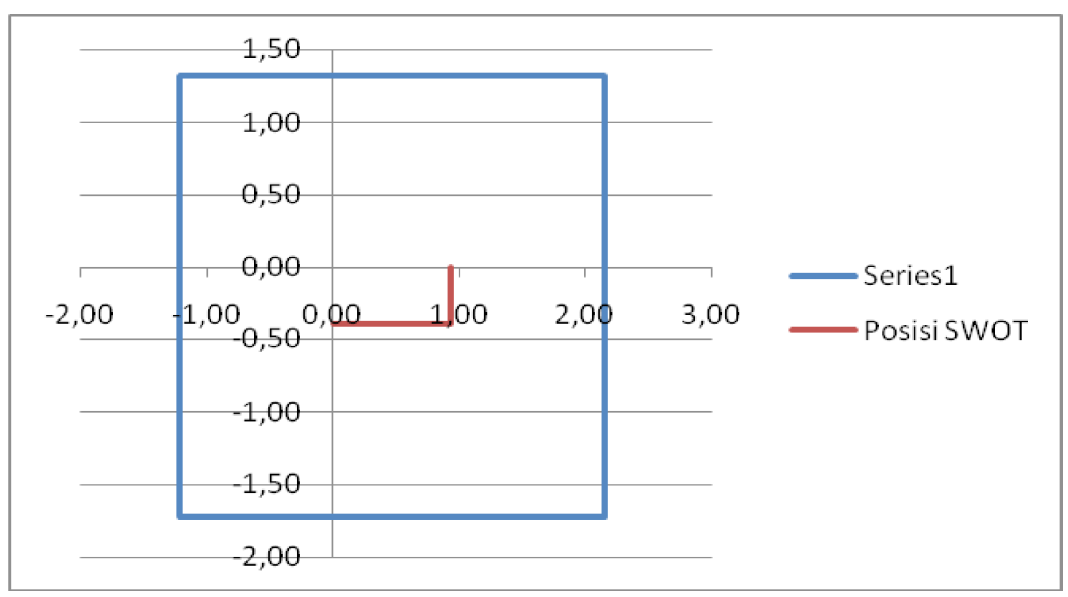

Gambar 2. Posisi pengembangan kawasan bawang merah di Kabupaten Bima 
Tabel 6. IFAS dan EFAS

\begin{tabular}{|c|l|l|}
\hline EFAS & Strength $(\mathrm{S})$ & Weaknesses $(\mathrm{W})$ \\
& & \\
\hline Opportunities $(\mathrm{O})$ & $\begin{array}{l}\text { Strategi SO } \\
=2,16+1,32=3,48\end{array}$ & $\begin{array}{l}\text { Strategi WO } \\
=1,22+1,32=2,54 \\
\end{array}$ \\
\hline Threats $(\mathrm{T})$ & $\begin{array}{l}\text { Strategi ST } \\
=2,16+1,72=3,88\end{array}$ & $\begin{array}{l}\text { Strategi WT } \\
\end{array}$ \\
& $=1,22+1,72=2,94$ \\
\hline
\end{tabular}

Salah satu strategi adalah dengan penerapan pola tanam yang baik, yaitu mengatur pertanaman bawang merah yang tidak serempak sehingga dapat menjaga kesinambungan pasokan dan kontinuitas penawaran bawang merah di pasaran (Mayrowani \& Darwis, 2007). Faktor yang mendukung untuk dilakukan pengaturan pola tanam adalah kekuatan yang dimiliki oleh kabupaten Bima yaitu dapat menanam sepanjang tahun karena iklim yang sesuai untuk pengembangan bawang merah, mempunyai dua varietas lokal yaitu Keta Monca yang dapat ditanam pada musim hujan dan Super Philip yang ditanam pada musim kemarau dan pengalaman bertani bawang merah.

Konsolidasi antar pemerintah daerah dan pusat perlu dilakukan untuk mengatur pola tanam bawang merah antar daerah, sehingga tidak terjadi panen raya serempak di semua lokasi produksi bawang merah. Dalam penelitian yang dilakukan, (Kustiari, 2017) menyebutkan bahwa barometer harga bawang merah adalah pasar Jawa Tengah, sehingga pemerintah harus dapat mengendalikan jumlah produksi dan pasokan untuk menjaga stabilitas harga bawang merah. Diharapkan melalui Bulog dapat menyerap bawang merah dengan harga layak pada saat panen raya dan dipasarkan kepada konsumen dengan harga yang terjangkau.

\section{KESIMPULAN DAN SARAN}

Pengembangan bawang merah di Kabupaten Bima mempunyai kekuatan yang lebih besar dari kelemahan, namun terdapat ancaman yang besar pula dibandingkan dengan peluang yang ada. Untuk itu strategi yang terbaik ialah strategi Strength-Threat (ST).
Saran strategi yang dilakukan ialah penerapan teknologi budidaya dan pengaturan pola tanam dengan memanfaatkan varietas lokal Keta Monca dan Super Philips. Selain itu, peningkatan peran Bulog dan penambahan fasilitas gudang untuk menyimpan bawang merah saat panen raya.

\section{UCAPAN TERIMA KASIH}

Ucapan terima kasih disampaikan kepada Kepala Puslitbang Hortikultura yang telah memfasilitasi kegiatan penelitian ini, serta kepada tim peneliti sosial ekonomi dan inovasi pertanian di Puslitbang Hortikultura atas kerjasama yang baik selama proses penelitian dilaksanakan.

\section{DAFTAR PUSTAKA}

Aji, A. A., Satria, A., \& Hariono, B. (2014). Strategi Pengembangan Agribisnis Komoditas Padi Dalam Meningkatkan Ketahanan Pangan Kabupaten Jember. Jurnal Manajemen Dan Agribisnis, 11(1), 60-67.

Aldila, H. F., Fariyanti, A., \& Tinaprilla, N. (2017). Daya Saing Bawang Merah Di Wilayah Sentra Produksi Di Indonesia. Jurnal Manajemen Dan Agribisnis, 14(1), 43-53. https://doi.org/10.17358/ jma.14.1.43

Basuki, R. (2014). Identifikasi Permasalahan dan Analisis Usahatani Bawang Merah di Dataran Tinggi Pada Musim Hujan di Kabupaten Majalengka ( Problems Identification and Shallots Farming Analyze in the Highland at Rainy Season in Majalengka District ), 24(3), 266-275.

Budiaji, W. (2013). Skala Pengukuran dan Jumlah Respon Skala Likert. Jurnal Ilmu Pertanian Dan Perikanan, 2(2), 127-133. 
Dinas Pertanian Kabupaten Bima, 2015. Pengembangan Komiditi Bawang Merah Di Kabupaten Bima

Enteding, T., Handayani, \& Adam, R. P. (2016). Analisis Pemasaran dan Strategi Pengembangan Komoditi Kedelai di Desa Nipa Kalemoan Kecamatan Bualemo Kabupaten Banggai. Jurnal Sains Dan Teknologi Tadulako, 3(3), $11-24$

Irfan, M. (2013). Respon Bawang Merah (Allium ascalonicum L) Terhadap Zat Pengatur Tumbuh dan Unsur Hara. Jurnal Agroteknologi, Vol 3(No 2), 35-40.

Kemendag. (2015). Potensi Bawang Merah di Kabupaten Bima.

Kustiari, R. (2017). Perilaku Harga dan Integrasi Pasar Bawang Merah di Indonesia, 35(2), 77-87.

Mayrowani, H., \& Darwis, V. (2007). Perspektif Pemasaran Bawang Merahdi kabupaten Brebes, Jawa Tengah.

Mehran, Kesumawati, E., \& Sufardi. (2013). Pertumbuhan dan Hasil Beberapa Varietas Bawang Merah (Allium ascalonicum L) Pada Tanah Aluvial Akibat Pemberian Berbagai Dosis Pupuk NPK. J Floratek, 11(2), 117-133.

Nuryanti, S., \& K.S.Swastika, D. (2011). Peran Kelompoktani dalam Penerapan Teknologi Pertanian. Forum Penelitian Agro Ekonomi, 29(70), 115-128.

Putra, A. A., \& Djalante, S. (2016). Pengembangan Infrastruktur Pelabuhan Dalam Mendukung Pembangunan Berkelanjutan. Jurnal Ilmiah Media Engineering, 6(No. 1), 433-443.

Rahayu, W. (2011). Strategi Pengembangan Komoditas Pertanian Unggulan Di Kecamatan Kalitidu Kabupaten Bojonegoro. SEPA, 7(2), 127-134.
Rauf, R. A., Darman, S., \& Andriana, A. (2015). Pengembangan Usahatani Bawang Merah Varietas Lembah Palu dan Strategi Analisis SWOT. Agriekonomika, 4(2), 245-257.

Santoso, D. J. (2013). Strategi Pengembangan Bawang Merah Dalam Rangka Peningkatan Pendapatan Petani di Kabupaten Nganjuk. Jurnal Manajemen Agribisnis, 13(2), 69-82.

Sekretaris Direktorat Jenderal Hortikultura. (2015). Statistik Produksi Hortikultura Tahun 2014. Statistik Produksi Hortikultura Tahun 2014, 286.

Simatupang, S. (2017). Kajian usahatani bawang merah dengan paket teknologi good agriculture practices. Jurnal Pengkajian Dan Pengembangan Teknologi Pertanian, Vol 20(1), 13-24.

Suryani, E., Erwidodo, \& Anugerah, I. S. (2014). Sistem Resi Gudang di Indonesia : ANtara Harapan dan Kenyataan. Analisis Kebijakan Pertanian, 12 No.1, 69-86.

Syahyuti. (1998). Beberapa Karakteristik dan Perilaku Pedagang Pemasaran KomoditasHasil-Hasil Pertanian di Indonesia. Forum Agro Ekonomi, 16(1), 42-53.

Wandschneider, T., Andri, K. B., Krisnadi, \& Puspadi, K. (2012). Analysis of Shallot Value Chains. ACIAR, GPO Box 1571, Canberra ACT 2601 Australia. Retrieved from http://www.who.int/iris/ handle/10665/107302

Waridjo, \& Fallo, Y. M. (2016). Strategi Pengembangan Usahatani Bawang Putih dalam Upaya Peningkatan Pendapatan Petani di Kecamatan Miomaffo Barat. Jurnal Agribisnis Lahan Kering, 1, $10-12$.

www.bps.go.id. 